\title{
A comparative study to assess surface water's anthropic and natural vulnerability using the DKPR and RUSLE approaches. Case of the watershed of the Joumouaa dam (Coastal basin of Ghiss, North East Morocco)
}

\author{
Soukaina Mansour ${ }^{1, *}$, Taoufiq Kouz ${ }^{1}$, Abdeldjalil Belkendil ${ }^{2}$, and Hinde Cherkaoui Dekkaki ${ }^{1}$ \\ ${ }^{1}$ Laboratory of Research and Development in Engineering Sciences. Research Team: Applied Geosciences and Geological Engineering. \\ Department of Earth and Environmental Sciences. Faculty of Science and Technique of Al Hoceima-Abdelmalek Essaadi University. \\ Morocco. \\ ${ }^{2}$ Laboratory Water Resources Valorisation, Science and Technology Faculty, University of Tlemcen, Chetouane. Algeria.
}

\begin{abstract}
The salinization of surface water in a coastal context leads to a qualitative degradation of this resource by various sources of anthropogenic and natural pollution. In this context, we present the results of a comparative study using "DKPR" and "RUSLE" models to evaluate the degree of surface water vulnerability against pollution, especially in the sub-watershed of the Joumouaa dam, a hydraulic infrastructure providing drinking water for the Targuist city. The "DKPR" model adopted as a qualitative approach involves four parameters: Accessibility of the aquatic environment (D), Water functioning of the soil and subsoil (K), Physiography watershed $(\mathrm{P})$, Rainfall erosivity $(\mathrm{R})$. The final result is a resource vulnerability map obtained by combining index maps of these four parameters using remote sensing and GIS. The "RUSLE" model applied as a quantitative approach integrates five factors in a multiplying function, namely: rainfall erosivity $(\mathrm{R})$, soil erodibility (K), slope length and steepness (LS), cover-management (C), and soil conservation practices $(\mathrm{P})$ in a remote sensing and GIS environment. The analysis of the final vulnerability maps of the approaches mentioned above will be helpful support for water resource managers and decision-makers better identify areas of high risk and their protection.
\end{abstract}

\section{Introduction}

Surface water is considered the main water resource used for drinking water, irrigation, and industry. Thus, this resource exists in various forms available globally, namely springs, ocean ponds, and lakes [1]. Unfortunately, due to anthropogenic origin, natural and the effects of climate change will impact water use. This situation constitutes a significant problem whose degradation is expressed by salinization and contamination of waters that represents a constraint in coastal areas limiting the development of a region. In this context, the concept of "vulnerability" has been developed to determine which areas are more susceptible to pollution. Therefore, assessing surface water vulnerability is also necessary to understand the pressure on water resources [2] and design strategies that minimize these pressures.

In this study, the vulnerability to contamination of the waters of the sub-catchment of the Joumouaa dam, the source of the drinking water supply of the city of Targuist is assessed using the DKPR approach developed by the bureau of geological and mining research (BRGM) [3]. This approach has been widely used by many researchers $[4,5]$. Thus, they obtained relevant results. In addition, the other approach, the Revised Universal Soil Loss Equation (RUSLE) [6], adjusted to local conditions. Its use is widespread in the Moroccan Rif to provide estimates of soil loss [7, 8].

The main objective of this paper is to apply a comparison between two approaches, one qualitative "DKPR"; to assess the vulnerability to water contamination of the Joumouaa dam of anthropogenic origin, and the other quantitative "RUSLE"; aims to map areas subject to a risk of water erosion of natural origin, to analyze the control factors and quantify the loss of soil at regional scale in a GIS and remote sensing environment. The results obtained are auspicious for optimal management of the quality of water resources and the protection of drinking water catchments.

\section{Materiel and methods}

\subsection{Study Area}

The studied basin corresponds to the sub-catchment of the Joumouaa dam, the main hydraulic infrastructure providing drinking water to the city of Targuist. It is part of the upstream zone of the Ghiss river basin. It is located

\footnotetext{
* Corresponding author: smansour@gmail.com
} 
in the northeast of the central Moroccan Rif, a few kilometers from the city of Al-Hoceima (Fig. 1.). It covers a total area of $52.07 \mathrm{Km}^{2}$ with a perimeter of $34.5 \mathrm{~km}$. From a topographic point of view, the study area is characterized by an essential altitudinal variation going from $931 \mathrm{~m}$ at its outlet to $2051 \mathrm{~m}$ on the highest summit.

The prevailing climate is semi-arid to humid with a hot, dry summer and a wet, rainy winter. Rainfall is characterized by seasonal and annual irregularities with an average annual rainfall of $340 \mathrm{~mm}$ [9]. On the other hand, the highest average monthly temperature is $28^{\circ} \mathrm{C}$, while the lowest is $7^{\circ} \mathrm{C}[10]$.

The region's hydrogeology characterized the coastal aquifer of Ghiss-Nekkour, which circulates below the studied sub-basin. This aquifer plays an important role in the agriculture and drinking water supply of the $\mathrm{Al}$ Hoceima city and its hinterland [11]. The bound waters are subject to challenges that threaten their sustainability due to salinization related to marine intrusion and anthropogenic pollution, and overexploitation resulting from the increasing demand for water due to the socioeconomic development that the region as a whole is experiencing [11-13].

From a hydrological point of view, the study area is drained by Oued Joumouaa, and fed by the tributary of river Hmayed.

Geologically, the sub-catchment area is located in the rif a domain where three structural domains outcrop: The flysch domain is represented by the Jbel Tizirene nappe, composed of marly-calcareous-sand stone flysch, and by the Jbel Chouamat nappe represented by schistose flysch. The formations of the external zones cover almost all the studied territory; they are represented by the unit of Ketama and the unit of Beni Bou Yacoub. The internal area is mainly constituted by the unit of the limestone ridges with massive non-metamorphic limestones of the Jurassic age [14]. Moreover, the quaternary formations appear only in the downstream part of the studied subbasin.

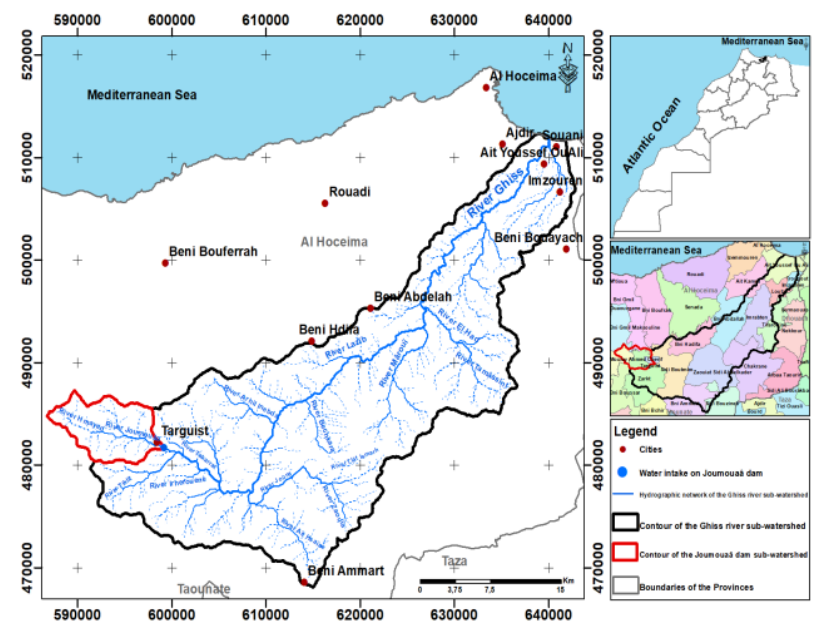

Fig.1. Location map of the study area

\subsection{Principle and application of the DKPR and RUSLE approach}

\subsubsection{Principles of DKPR Model}

The DKPR approach is based on the principle of parametric methods, using a system of weighted classes. It consists of evaluating the vulnerability of surface waters to contamination. The criteria used in the method are:

Aquatic Accessibility (D): Represents the hydraulic distance from each point to the nearest stream in its topographic basin. The class value assigned to this factor is inversely proportional to the distance "D" Table 1.

The hydrological functioning of the soil and subsoil (K): This parameter provides information on the partition between infiltration water and runoff water. Thus, the determination of this factor is done through the evaluation of the classes of three parameters, namely: the index of development and persistence of the networks "IDPR", the index of battance "IB" and the occupation of the ground "Os" Table 1. According to the equation below proposed by the DKPR method:

$K=a I D P R+b I B+c \quad O s$

With:

$\mathbf{K}$ : Index referring to the water functioning of the soil and the subsoil;

IDPR: Index class for network development and persistence index;

IB: Slaking index class;

Os: Land use class.

With: $\mathrm{a}=0.4 ; \mathrm{b}=0.2$ and $\mathrm{c}=0.4$ for $\mathrm{a}+\mathrm{b}+\mathrm{c}=1$

The physiography of the watershed "P": This parameter governs the runoff of surface water through the intensity of the slopes "Pi" and their shape (in relation to the curves) "Pc" Table 1, knowing that:

$P=d P i+e P c$

With: $\mathrm{d}=0.8$ and $\mathrm{e}=0.2$ for $\mathrm{d}+\mathrm{e}=1$

P: Watershed physiography criterion;

Pi: Slope intensity class;

Pc: Slope curvature class.

Rainfall erosivity "R": This factor is related to the intensity of rainfall. Thus, Renard and Freimund [15], propose a simplified formula integrating only the average annual rainfall $\mathrm{P}$ (in $\mathrm{mm}$ ) Table 1:

$R=0.04830 P^{1.610}$

Where:

R: Erosivity parameter;

$\mathrm{P}$ : Annual precipitation ( $\mathrm{mm}$ ).

The final degree of vulnerability " $\mathrm{Vr}$ " is the result of the sum of the products of each class by its weighting factor according to the following expression:

$V r=f D+g K+h P+i R$

With:

Vr: Vulnerability index of the resource; 
D: Class related to the accessibility to watercourses;

$\mathrm{K}$ : Class related to the hydric functioning of the soil and subsoil;

P: Class related to the slopes;

R: Rainfall erosivity class;

Where $\mathrm{f}, \mathrm{g}, \mathrm{h}$ and $\mathrm{i}$ are weighting factors: $\mathrm{f}=0.3 ; \mathrm{g}=0.4$; $\mathrm{h}=0.2$ and $\mathrm{i}=0.1$.

Table 1.Matrix generating the partial parametric indices [3]

\begin{tabular}{|c|c|c|c|c|c|}
\hline \multirow{2}{*}{ Parameter } & \multicolumn{5}{|c|}{ Degree of vulnerability and classes } \\
\cline { 2 - 6 } & $\begin{array}{c}\text { Very } \\
\text { High }\end{array}$ & High & Moderate & Low & $\begin{array}{c}\text { Very } \\
\text { Low }\end{array}$ \\
\cline { 2 - 6 } & 4 & 3 & 2 & 1 & 0 \\
\hline D & $0-50 \mathrm{~m}$ & $\begin{array}{c}50-100 \\
\mathrm{~m}\end{array}$ & $\begin{array}{c}100-200 \\
\mathrm{~m}\end{array}$ & $\begin{array}{c}200-500 \\
\mathrm{~m}\end{array}$ & $>500 \mathrm{~m}$ \\
\hline $\mathbf{K}$ & $3.2-4$ & $2.4-3.19$ & $1.6-2.39$ & $0.8-1.59$ & $0-0.79$ \\
\hline $\mathbf{P}$ & $3.2-4$ & $2.4-3.19$ & $1.6-2.39$ & $0.8-1.59$ & $0-0.79$ \\
\hline $\mathbf{R}$ & $\begin{array}{c}>5000 \\
\mathrm{~mm}\end{array}$ & $\begin{array}{c}4000 \mathrm{to} \\
5000 \mathrm{~mm}\end{array}$ & $\begin{array}{c}3000 \mathrm{to} \\
4000 \mathrm{~mm}\end{array}$ & $\begin{array}{c}2000 \text { to } \\
3000 \mathrm{~mm}\end{array}$ & $\begin{array}{c}0 \text { to } 2000 \\
\mathrm{~mm}\end{array}$ \\
\hline
\end{tabular}

Then, each pixel in the resource vulnerability map is assigned a value that determines its degree of resource is associated with a value determining its degree. Table 2 shows the classification of these vulnerability values.

Table 2.Classes of resource vulnerability indices [3]

\begin{tabular}{|c|c|c|}
\hline $\begin{array}{c}\text { Vulnerability } \\
\text { class }\end{array}$ & $\begin{array}{c}\text { Value of the } \\
\text { Index Vr }\end{array}$ & $\begin{array}{c}\text { Degree of } \\
\text { vulnerability }\end{array}$ \\
\hline $\mathbf{4}$ & $3.2-4$ & Very High \\
\hline $\mathbf{3}$ & $2.4-3.19$ & High \\
\hline $\mathbf{2}$ & $1.6-2.39$ & Moderate \\
\hline $\mathbf{1}$ & $0.8-1.59$ & Low \\
\hline $\mathbf{0}$ & $0-0.79$ & Very Low \\
\hline
\end{tabular}

\subsubsection{Principles of RUSLE Model}

The revised universal soil loss equation [6] is an improved version of the USLE model of Wischmeier and Smith [16]. This empirical model combines the five significant factors controlling water erosion. It has been recognized as the most commonly used model for quantifying soil losses due to water erosion and spatially locating high priority areas for intervention in the study area.

The Universal Soil Loss Equation (USLE) is written:

$$
\mathrm{A}=\text { R. K. LS. C. P }
$$

Where:

A: Annual soil loss in $\mathrm{t} / \mathrm{ha} /$ year;

$\mathrm{R}$ : Climatic aggressiveness factor in MJ.mm/Ha.H.year;

$\mathrm{K}$ : Soil erodibility expressed in t.ha.H/ha.MJ.mm;

LS: Factors of slope inclination and length (dimensionless);

C : Vegetation cover factor (dimensionless);

$\mathrm{P}$ : Factor of anti-erosion practices (dimensionless)
Rainfall erosivity (R): This factor presents the impact of the erosive force of rainfall on the soil. According to [16], the estimation of this index requires the determination of the kinetic energies and the maximum intensity over thirty consecutive minutes of the raindrops of each shower. Due to the lack of this type of data, some authors have developed alternative formulas that do not require detailed rainfall records but consider the average monthly and annual intensities to determine the $\mathrm{R}$ factor $[17,18]$. For this, we choose the formulas of Rango and Arnoldus [18] it is given below:

$\log R=1.74 \log \sum_{i=1}^{12}\left(\frac{P_{i}{ }^{2}}{P}\right)+1.29$

With:

Pi: Average monthly precipitation;

P: Average annual precipitation;

$\mathrm{R}$ : Climatic aggressiveness in $\mathrm{MJ} \mathrm{mm} / \mathrm{ha} \mathrm{H}$ year.

Soil erodibility (K): expresses its sensitivity to water erosion and depends on its intrinsic properties such as its texture, structure, and permeability. Faced with the lack of these data types, we have developed the erodibility map based on previous work according to soil types characterizing the sub-basin studied $[19,20]$.

Slope length and steepness (LS): influences the rate of sediment loss, which is related to a significant increase in flux resulting from an increase in slope length and slope steepness [21]. Thus, the LS factor was calculated using the formula of Wischmeier and Smith [16], with modifications by [22] (Eq. 10).

$L S=\left(\frac{L}{22.13}\right)^{m}+\left(0.065+0.045 S+0.0065 S^{2}\right)$

Where $\mathrm{S}$ is the slope gradient in $\%$; $\mathrm{L}$ is the length of the slope in meters. $\mathrm{L}=$ flow accumulation $\times$ DEM spatial resolution. Otherwise, the value of " $\mathrm{m}$ " varies between 0.2 and 0.5 depending on slope percentage. A value of 0.2 is attributed to areas with slope $<1 \%$, values of 0.3 and 0.4 correspond, respectively, to areas with slope percentages that vary between $1-3$ and $3-5$, and a value of 0.5 is attributed to areas with slopes $>5 \%$ [16-22].

Vegetation cover factor (C): The index (C) represents the ratio of soil loss for a plot with a given vegetation cover and cropping practices to the rate of soil loss for a plowed and left bare plot. The generation of the raster layer of the $\mathrm{C}$ factor from the NDVI is written as follows [23-25]:

$C=\exp \left[\frac{-\alpha N D V I}{-\beta N D V I}\right]$

Where:

C: Vegetation cover factor; NDVI $=(\mathrm{R} 5-\mathrm{R} 4) /(\mathrm{R} 5+$ $\mathrm{R} 4)$; $\alpha$ and $\beta$ are constants ( $\alpha=2$ and $\beta=1)$ [26].

Soil conservation practices $(\mathbf{P})$ : Contour cropping, bench planting are very effective water and soil conservation practices. According to [16], the values of (P) are less than or equal to 1 . The value of 1 is assigned to land on which there are no erosion control practices. 


\section{3 used Database}

Several types of data from different sources were used:

- Digital Terrain Model (DTM) of $30 \mathrm{~m}$ resolution;

- Landsat 8 Oli images with a resolution of $30 \mathrm{~m}$;

- Geological map of the rif chain at 1/500 000 scales provided by the ministry of energy and mines and sustainable development (geology department) Morocco;

- Pedological map of the rif and the oriental brought to $1 / 500000$ and provided by the ministry of agriculture of rural development and water and forests;

- Rainfall data from stations located in and around the study area for an observation period between 1989 and 2018 were obtained from the Worldclim database in raster format (ESRI grids) with a resolution of 2.5 minutes (about $21 \mathrm{~km}^{2}$ ).

\section{Results and discussions}

\subsection{DKPR approach}

At the end of the application of the DKPR approach to evaluate the vulnerability of the waters of the subcatchment of the Joumouaa dam to pollution, the final map of the intrinsic vulnerability of the waters of the studied sub-basin is represented as a qualitative map (Fig. 2.). It shows that the dominant class being of a moderate degree. It covers up to $61.22 \%$ of the total area of the studied territory. The rest of the studied area is represented by very low, low, and high classes occupying $25.31 \%, 13.38 \%$, and $0.09 \%$. Thus, the confrontation of the four index maps obtained showed that the final map resulting takes the general appearance of the two index maps related to the criteria D and $\mathrm{P}$. In this sense, the parameter " $\mathrm{D}$ " is considered one of the most important because it contributes most to the vulnerability of surface water. In addition, the most stable parameter is $\mathrm{R}$.

Comparisons can be made with previous work undertaken in the Moroccan rif watersheds using the same approach $[4,5]$. The results obtained are similar to those found in these recent studies.

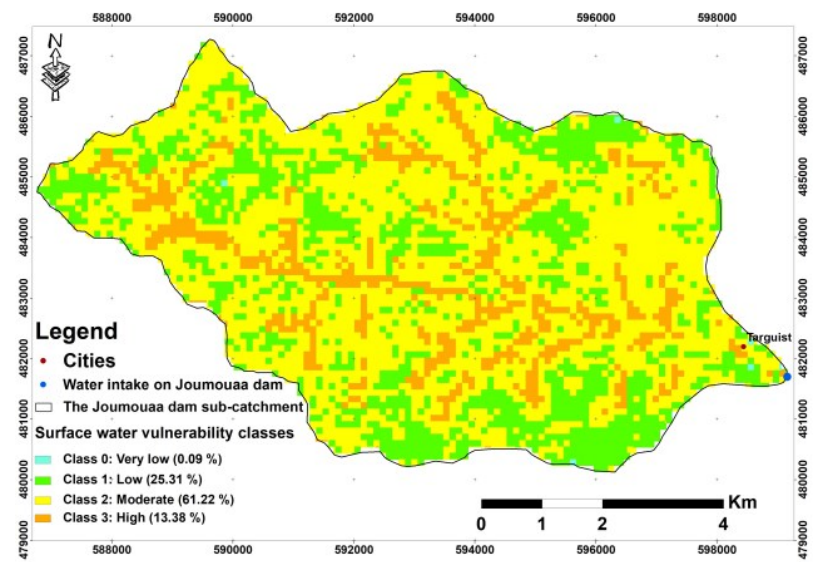

Fig. 2. Vulnerability of the surface waters of the Joumouaa dam sub-catchment

\subsection{RUSLE approach}

Overlaying the raster data layers of the model factors $(\mathrm{R}, \mathrm{K}$, LS, C, and P) were organized under the step of a grid with a cell size of $30 \mathrm{~m} \times 30 \mathrm{~m}$ in a GIS environment provides a quantitative map estimating soil loss in the studied basin per spatial unit. These factors vary as follows:

- Climate Aggressiveness (R) Map: from 76.92 to 78.73 $\mathrm{MJ} \mathrm{mm} / \mathrm{ha} \mathrm{H}$ year.

- Topographic factor map (LS): from 0 à 42.79 .

- Soil erodibility map (K): from 0.23 to 0.46 tha $\mathrm{H} / \mathrm{ha} \mathrm{MJ} \mathrm{mm.}$

- Vegetation cover map (C): from 0.07 to 1.

- Soil conservation practices $(\mathrm{P})$ : no practice is carried out at the level of the study area, and for that, we considered this factor is equal to 1 .

The final result reveals an average annual soil loss ranging from 0 to $807.14 \mathrm{t} / \mathrm{ha} /$ year with an average of $16.71 \mathrm{t} /$ ha/year (Fig. 3.). In addition, the soil loss map was grouped according to a classification adopted by FAO [27]. The areas with soil loss between 0 and $5 \mathrm{t} / \mathrm{ha} /$ year and represent $84 \%$ of the basin area and are distributed throughout the basin and generally follow the spatial distribution of low altitude and low slope areas, which highlights the effect of the topographic factor, especially the slope, in the water erosion process.

The areas with erosion rates ranging from 5 to 50 t/ha/year occupy $6.69 \%$. The areas with a high risk of erosion, containing the classes with erosion rates between 50 and $100 \mathrm{t} / \mathrm{ha} /$ year, represent $4.48 \%$ of the studied territory. The areas with a very high erosion risk with values $>100 \mathrm{t} / \mathrm{ha} /$ year also represent $4.74 \%$ of the area and follow the very steep slopes of the watershed.

The analysis of the results obtained with the RUSLE model highlights a medium vulnerability to water erosion, reflecting different erosion factors, mainly the topographic factor LS.

A comparison of the results obtained with previous works is necessary. Thus, the value of average annual soil loss (16.71t/ha/year) obtained in the studied basin is close to the values obtained in other similar environments [28, 29 ] and lower than those obtained by others in the same geographical context $[7,8]$.

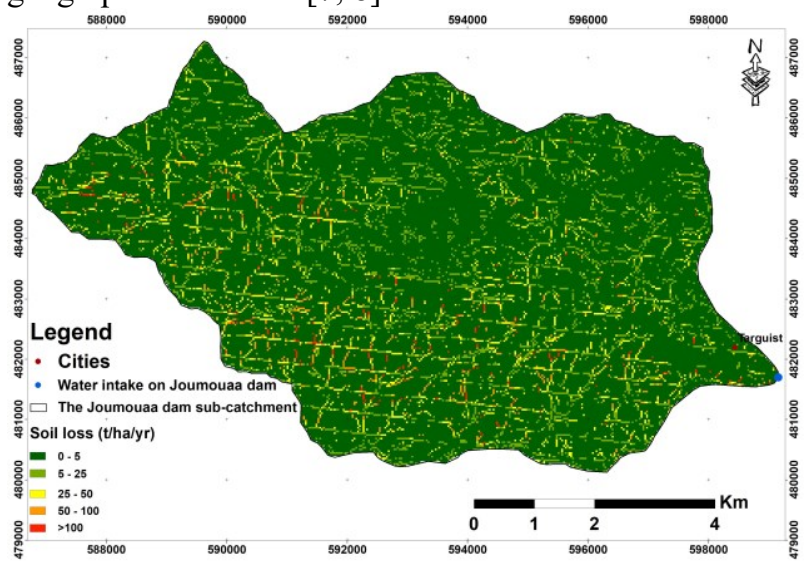

Fig. 3. Spatial distribution of soil losses 


\section{Conclusion}

The evaluation of the vulnerability of anthropic and natural origin at the level of the Joumouaa sub-catchment using the RUSLE and DKPR models in a GIS and remote sensing environment has highlighted the areas most exposed to erosion, thus polluting the responsible factors in order to ensure qualitative and quantitative management of the resource.

In this study, the results obtained from the DKPR model show that the dominant class being of a moderate degree of vulnerability where the parameter " $D$ " contributes the most to the vulnerability of surface water. Concerning the RUSLE approach, the average annual soil erosion rate in the studied watershed was estimated at $16.71 \mathrm{t} / \mathrm{ha} /$ year, mainly due to the influence of the topography. Thus, both approaches show a medium degree of vulnerability. In addition, these results could be used as an aid to decision-makers and planners when making decisions in water and soil management and preservation.

The application of the DKPR and RUSLE approaches, despite some limitations, is beneficial for mapping areas at high risk of pollution and erosion, even in the absence of data. Both methods could be improved by obtaining more accurate data for the DKPR and RUSLE factors, such as precipitation data to better estimate the erosivity of precipitation and soil data to determine the $\mathrm{K}$ factor.

\section{References}

1. R. Bhateria, D. Jain. Water quality assessment of lake : a review. Sustain Water Resour Manag 2, 2 (2016)

2. A. Anandhi, N. Kannan. Vulnerability assessment of water resources-translating a theoretical concept to an operational framework using systems thinking approach in a changing climate: case study in Ogallala Aquifer. J Hydrol 557, 460-474 (2018)

3. D. Douay, E. Lardieg. Délimitation des aires d'alimentation des captages prioritaires du bassin Adour Garonne : méthodologie de cartographie de la vulnérabilité intrinsèque des captages d'eau superficielle. Agence de l'Eau ADOUR GARRONE, ANTEA -GINGER Environnement \& Infrastructures - CALLIGEE, 28 (2010)

4. I. Hilal, J.S. El Messari, J.G. Moreno Navarro, M.R.A. Mansour, H. M. Zerrouk. Application du modèle DKPR pour la cartographie de la vulnérabilité des eaux de surface à la contamination : cas du barrage 9 avril 1947 (Maroc septentrional). Revue des sciences de l'eau 31, 1 (2018)

5. S. Mansour ,T. Kouz, M. Thaiki, A. Ouhadi, H. Mesmoudi, M. H Zerrouk, T. Mourabit, H. Dakak \& H.Cherkaoui Dekkaki. Spatial assessment of the vulnerability of water resources against anthropogenic pollution using the DKPR model: a case of Ghiss-Nekkour basin, Morocco. Arab.J.Geosci 14, 8 (2021)

6. K.G. Renard, G.R. Foster, G.A. Weesies, D.K McCool, D.C Yoder. Predicting soil Erosion by water: a guide to conservation planning with the Revised Soil Loss Equation(RUSLE) - Agriculture Handbook. USDA, Washington, 703 (1997)

7. A. Sadiki, S. Bouhlassa, J. Auajjar, A. Faleh, J.J. Macaire. Utilisation d'un SIG pour l'évaluation et la cartographie des risques d'érosion par l'Equation universelle des pertes en sol dans le Rif oriental (Maroc): cas du bassin versant de l'oued Boussouab. Bull l'Inst Sci Rabat, 26 (2004)

8. L. Khali Issa, K. Ben Hamman Lech-Hab, A. Raissouni, A. El Arrim. Quantitative Mapping of Soil Erosion RiskUsing GIS/USLE Approachat the KalayaWatershed (North Western Morocco). J. Mater. Environ. Sci 7, 8 (2016)

9. Niazi S, Snoussi M, Foutlane A. Impact des aléas climatiques sur la qualité des eaux d'un hydrosystème aménagé en zone semi-aride : cas du bassin-versant du Nekkor (Maroc). Sécheresse (Montrouge) 16, 3 (2005)

10. N. Arrebei, M. Sabir, M. Naimi, M. Chikhaoui, D. Raclot. Reconstitution des données historiques et diagnostic de l'état actuel des aménagements antiérosifs dans le bassin versant Nekor. Rev. Mar. Sci. Agron. Vét 7, 2 (2019)

11. T. Kouz, H. Cherkaoui Dekkaki, S. Mansour, M. Hassani Zerrouk, T. Mourabit. Application of GALDIT Index to Assess the Intrinsic Vulnerability of Coastal Aquifer to Seawater Intrusion Case of the Ghiss-Nekor Aquifer (North East of Morocco). In: Calvache M, Duque C, Pulido-Velazquez D (eds) Groundwater and Global Change in the Western Mediterranean Area. Environmental Earth Sciences. Springer, Cham, 169-177(2017)

12. T. Kouz, S. Mansour, T. Mourabit, H. Cherkaoui Dekkaki. Application of the "PRK Plus" approach to evaluate the sensitivity of the Coastal Aquifer of Ghiss-Nekkour against pollution (North East of Morocco). La Houille Blanche, 5-6 (2019)

13. T. Kouz, S. Mansour, H. Mesmoudi, H. Dakkak, H. Cherkaoui Dekkaki. Assessment of groundwater vulnerability to pollution as part of integrated management in coastal area. Case of Ghiss-Nekkour basin (North East of Morocco). La Houille Blanche 106, 2 (2020)

14. A. Michard, A. Chalouan , H. Feinberg, B. Goffé, Montigny R. How does the Alpine belt end between Spain and Morocco. Bull. Soc. Géol 173,1 (2002)

15. K.G. Renard, J.R. Freimund. Using monthly precipitation data to estimate the R-factor in the revised USLE. Journal of Hydrology 157,1-4 (1994)

16. W.H. Wischmeier, DD. Smith. Predicting Rainfall Erosion Losses - A Guide to Conservation Planning. Agriculture Handbook. Department of Agriculture Science and Education Administration, Washington, District of Columbia USA. US 537, 58 (1978)

17. H.M.J Arnoldus. Methodology used to determine the maximum potential average annual soil loss due to sheet and rill erosion in Morocco. Soils Bulletins FAO 34, 39-48 (1977) 
18. A. Rango, H.M.J. Arnoldus. Aménagement des bassins versants. In : Cahiers techniques de la FAO 1-11(1987)

19. A. El Garouani, H. Chen, L. Lewis, A. Tribak, M. Abharour. Cartographie de l'utilisation du sol et de l'érosion nette à partir d'images satellitaires et du Sig Idrisi au Nord-Est du Maroc, Teledetection, Editions des Archives Contemporaines / Editions scientifiques GB / Gordon and Breach Scientific Publishers 8, 3 (2009)

20. H. Mesrar. Modélisation, quantification et définition des facteurs qui contrôlent le risque de l'érosion hydrique. Cas du bassin versant de l'oued Sahla, Rif central, Maroc. Thèse de doctorat en Géologie, 369 (2016)

21. BP. Ganasri, H. Ramesh. Assessment of soil erosion by RUSLE model using remote sensing and GIS - a case study of Nethravathi Basin. Geosci Front 7,953961(2016)

22. A. Bizuwerk, G. Taddese, Y. Getahun. Application of GIS for modeling soil loss rate in Awash Basin, Ethiopia. International Live stock Research Institute, Addis Ababa, Ethiopia (2008)

23. P. Zhou, O. Luukkanen, T. Tokola, J.J. Nieminen. Effect of vegetation cover on soil erosion in a mountainous watershed. Catena 75, 3 (2008)

24. M. Kouli, P. Soupios, F.Vallianatos. Soil erosion prediction using the revised universal soil loss equation (RUSLE) in a GIS framework, Chania, North western Crete, Greece. Environ Geo 157, 483497 (2009)

25. V. J. Markose, K.S Jayappa. Soilloss estimation and prioritization of sub-watersheds of Kali River basin, Karnataka, India, using RUSLE and GIS. Environ Monit Assess 188, 225 (2016)

26. J.M. Van der Knijff, R.J.A. Jones, L. Montanarella .Soil erosion risk assessment in Europe, EuropeanSoil Bureau Research Report EUR 19044 ENp, 34 (2000)

27. FAO P UNESCO. Metodología provisional para la evaluación de la degradación de los suelos. Roma (1980)

28. A. Sadiki, A. Faleh, J.L. Zezerze, H. Mastass. Quantification de l'erosion en nappe dans le bassin versant de l'Oued Sahla, Rifoccidental Maroc. Cahiers Géographiques, 6 (2009)

29. A. Zouagui, M. Benmansour, N. Amenzou, A. Nouira, M. Sabir, H. Benjelloun, H. Marah, A. Benkadad. Application la technique de $137 \mathrm{Cs}$ à l'estimation de l'érosion hydrique dans le bassin versant de Moulay Bouchta, Rif occidental, Maroc. . Rev. Mar. Sci. Agron. Vét, 1 (2012) 